\title{
INSTITUCIONALIZAÇÃO DA HOMOFOBIA NO BRASIL: PROIBIÇÃO DE GAYS DOAREM DE SANGUE, A (IN) CONSTITUCIONALIDADE DO ARTIGO 64, INCISO IV DA PORTARIA 158/2016 E RESOLUÇÃO 34 DA ANVISA
}

Fabrício Veiga Costa ${ }^{1}$

\section{Resumo:}

Objetiva-se investigar a constitucionalidade da portaria 158/2016 do Ministério da Saúde e resolução 34/2014 da ANVISA, que proíbem que homens declaradamente gays sejam doadores de sangue. A escolha do tema se justifica em razão de sua relevância jurídica e prática, especialmente porque a homofobia é um fenômeno social naturalizado na sociedade brasileira. Por meio da pesquisa bibliográfica e documental, bem como análise da ADIN 5443, demonstrou-se a inconstitucionalidade a portaria 158 e resolução 34, por violarem a dignidade humana, princípio da não-discriminação, liberdade de escolha, direito fundamenta à igualdade e inviabilizar o exercício da cidadania.

Palavras-chave: Homofobia; Doação de sangue; Constitucionalidade; Portaria 158/2016 do Ministério da Saúde; Resolução 34/3014 ANVISA.

\section{INSTITUTIONALIZATION OF HOMOPHOBIA IN BRAZIL: PROHIBITION OF GAYS DONATE BLOOD, THE (IN) CONSTITUTIONALITY OF ARTICLE 64, PARAGRAPH 158/2016 AND RESOLUTION 34}

\begin{abstract}
:
The objective is to investigate the constitutionality of Ordinance 158/2016 of the Ministry of Health and ANVISA Resolution 34/2014, which prohibit men who are declared gay to be blood donors. The choice of theme is justified because of its legal and practical relevance, especially since homophobia is a naturalized social phenomenon in Brazilian society. Through bibliographic and documentary research, as well as analysis of ADIN 5443, the unconstitutionality of Ordinance 158 and Resolution 34 was demonstrated, as they violate human dignity, the principle of non-discrimination, freedom of choice, the fundamental right to equality and make the exercise of citizenship.
\end{abstract}

Keywords: Homophobia; Blood donation; Constitutionality; Ordinance 158/2016 of the Ministry of Health; Resolution 34/3014 ANVISA.

\section{Introdução}

Constitui objetivo geral da presente pesquisa investigar a constitucionalidade das proposições legais constantes na portaria 158/2016 do Ministério da Saúde e a Resolução

\footnotetext{
${ }^{1}$ Professor do Programa de Pós-Graduação Stricto Sensu em Proteção dos Direitos Fundamentais pela Universidade de Itaúna. Pós-doutorado em Educação pela UFMG. Doutorado e Mestrado em Direito Processual pela PUCMINAS.
}

Revista de Gênero, Sexualidade e Direito | e-ISSN: 2525-9849 | Belém | v. 5 | n. 2 | p. 33 - 54 | Jul/Dez. 2019. 
34/2014 da ANVISA, que proíbem expressamente homens gays doarem sangue no Brasil. A escolha do tema decorre de sua relevância jurídica e prática, haja vista a necessidade de demonstrar que tais premissas legais não se compatibilizam com as proposições trazidas pela constituição democrática brasileira de 1988, cujos pilares se encontram na proteção da dignidade humana, exercício da cidadania, aplicabilidade do princípio da não-discriminação e efetividade dos direitos fundamentais à liberdade e igualdade.

Inicialmente foi desenvolvido um estudo sobre o fenômeno histórico-social da homofobia, com o condão de desconstruir criticamente a naturalização do discurso de ódio contra gays. O estudo dos fundamentos da heteronormatividade compulsória, reflexo da doutrina binário-sexista criticada por Judith Butler, foi de fundamental importância para demonstrar que a homossexualidade é uma orientação decorrente da subjetividade situada de cada indivíduo que escolhe exercer livremente sua sexualidade para além dos padrões binários impostos e sedimentados socialmente. Realizou-se, ainda, breves apontamentos críticos acerca da patologização e criminalização da homossexualidade, como forma de evidenciar que o conhecimento cientifico é utilizado, muitas vezes, como referencial para legitimar e institucionalizar a segregação, marginalidade e preconceito contra homens gays.

$\mathrm{Na}$ sequência foi apresentada a portaria 158/2016 do Ministério da Saúde e a resolução 34/2014 da ANVISA (Agência Nacional de Vigilância Sanitária), expondo a existência de fundamentos legais que proíbem homens gays, que tenham mantido relação sexual nos últimos 12 (doze) meses, de serem doadores de sangue. Demonstrou-se que as referidas legislações infraconstitucionais não excepcionam a regra ora instituída e, por isso, inviabiliza para homens declaradamente gays a possibilidade de exercício de um dos direitos civis básicos, qual seja, a doação de sangue. Problematizou-se, ainda, as razões de tal proibição legal, de modo a esclarecer que a principal justificativa é que os gays integram grupo de risco e são considerados sujeitos com maior aptidão para o contágio e transmissão de doenças venéreas, institucionalizando-se, sob o ponto de vista legal, a homofobia.

O estudo da ação direta de inconstitucionalidade 5443, cujo objeto é a análise da constitucionalidade da portaria e resolução supramencionadas, foi de significativa importância na investigação da problemática cientifica proposta. A partir das premissas teóricas decorrentes dos princípios da dignidade humana e não-discriminação, bem como os direitos fundamentais à liberdade e igualdade, foi possível construir análises hábeis a verificar a 
constitucionalidade dos referidos dispositivos infraconstitucionais, além de evidenciar a institucionalização estatal de práticas homofóbicas contra homens gays.

A delimitação do objeto proposto se deu a partir da seguinte pergunta problema: quais são os fundamentos jurídicos utilizados como parâmetro para a análise da constitucionalidade da portaria 158/2016 do Ministério da Saúde e a resolução 34/2014 da ANVISA? Por meio da pesquisa bibliográfica e documental, análises temáticas, teóricas, interpretativas e comparativas foi possível demonstrar criticamente que tais proposições legislativas evidenciam a naturalização institucionalizada da homofobia, no momento em que pessoas são impedidas de doarem sangue em razão de sua orientação sexual. A utilização do método indutivo permitiu o recorte da pesquisa realizada, partindo-se de uma concepção microanalítica, qual seja, o estudo da portaria 158/2016 e da resolução 34/2014, ampliando-se o espectro de análise no debate da sua constitucionalidade.

\section{Institucionalização da homofobia e a naturalização do discurso de ódio contra gays.}

A investigação científica do fenômeno social da naturalização de práticas homofóbicas no Brasil objetiva esclarecer as razões que explicam a proibição de homens gays serem doadores de sangue, haja vista que na perspectiva social e estatal tais sujeitos integram grupo de risco, em razão de não se enquadrarem no modelo binário decorrente da heteronormatividade compulsória imposto pela modernidade.

Visando problematizar e esclarecer a temática apresentada, Judith Butler expõe que “a heterossexualização do desejo requer e institui a produção de oposições discriminadas e assimétricas entre feminino e masculino, em que estes são compreendidos como atributos expressivos de macho e de fềmea" (BUTLER, 2015, p. 44). Ou seja, "a matriz cultural por meio da qual a identidade de gênero se torna inteligível exige que certos tipos de identidade não possam existir - isto é, aqueles em que o gênero não decorre do sexo e aqueles em que as práticas do desejo não decorrem nem do sexo nem do gênero" (BUTLER, 2015, p. 44).

A invisibilidade do homem gay, sua marginalidade e segregação social decorrem do fato desses sujeitos transgredirem as normatividades impostas, rompendo com os padrões binário-sexistas de uma heterossexualidade inerente à condição humana. A heteronormatividade compulsória impõe a condição heterossexual como postura prevalente e reconhecida socialmente, ou seja, "a heterossexualidade é uma posição política hegemônica 
imposta como fato natural, uma necessidade ontológica colocada como imprescindível à inteligibilidade dos corpos e condição prévia da identidade humana - não se trata apenas de exclusão política e social" (MELLO, 2015, p. 233).

Em razão do padrão heterossexista construído e sedimentado socialmente, homens gays são vistos como aqueles que transgridem os padrões, que negam a natural condição heterossexual vigente e, por isso, são marginalizados, passando a integrar o grupo daqueles que destoam dos padrões sexualmente hegemônicos. São categorizados como grupo de risco em razão de a homossexualidade ser associada simbolicamente à promiscuidade. $\mathrm{O}$ gay é visto pela sociedade heteronormativa como aquele sujeito que tem intensa vida sexual, com inúmeros parceiros do mesmo sexo e, pelo fato de não privilegiarem relações monogâmicas, esses sujeitos são vistos como "aqueles mais propensos a disseminação de doenças sexualmente transmissíveis". Esse discurso subentendido ou explicito nas relações sociais é responsável por retroalimentar a homofobia, intensificando-se o ódio contra homens gays.

A partir dessas premissas sociais reproduzidas irracionalmente, foi institucionalizado o discurso de ódio contra homens gays, considerados grupo de risco inapto a doar sangue. As proibições legais que impedem o homem gay de doar sangue deixam claro que o Estado considera o sangue de homens gays como "um sangue impuro", tendo em vista que os mesmos integram o grupo daqueles sujeitos que gozam de uma "vida promíscua e com muitos parceiros sexuais", sendo considerados vetores e transmissores diretos de doenças sexualmente venéreas. Nessa perspectiva estatal, permitir que homens declaradamente gays sejam doadores de sangue é o mesmo que colocar em risco a sociedade civil, em razão da possibilidade de cidadãos sadios receberem sangue impuro e contaminado pela vida desregrada e promiscua desse grupo de sujeitos que negam a heteronormatividade compulsória.

A doutrina binária de classificação de corpos e a imposição de padrões de sexualidade decorre de premissas já solidificadas socialmente, nas quais o homem é o sujeito com pênis e a mulher o indivíduo com vagina, ressaltando-se que o relacionamento afetivosexual objetiva a procriação e a constituição de família, não essencialmente o prazer sexual. A partir do modelo imposto e proposto pela modernidade, aqueles sujeitos que não se enquadram nas ditas "caixinhas modernas de classificação de pessoas e condutas", são patologizados ou considerados autores de práticas criminosas. Esse modelo foi criado para reproduzir e enfatizar os ideários da heterossexualidade dominante e compulsória, endossando 
a exclusão e marginalidade de homens gays pelo fato de os mesmos destoarem desse padrão imposto e vigente.

Em 20 de abril de 2019 o Jornal Folha de São Paulo publicou reportagem informando que relação homossexual é crime em 70 países, como mostra relatório mundial. A contagem inclui apenas as 193 nações membros da ONU, ressaltando-se que 35\% desses países criminalizam a homossexualidade atualmente. A maioria desses países se encontra na África (33 países), sendo 22 na Ásia, 9 países na América e 6 na Oceania. As penalidades variam de multas, prisões (inclusive perpétua) e até morte, como é o caso do Irã, Arábia Saudita, Iêmen, Sudão, Somália e Nigéria (BRASIL, Jornal Folha de São Paulo, 2019). Importante ainda ressaltar que somente em 17 de maio de 1990 que a Organização Mundial de Saúde retirou a homossexualidade da lista internacional de doenças (SANTOS, 2019). "Lei da época do império que tipificava homossexualidade como crime foi retirada do Código Penal alemão apenas em 1994" (ALEMANHA, 2019), ou seja, "só então a relação entre pessoas do mesmo sexo deixou de ser oficialmente punível com prisão" (ALEMANHA, 2019).

No momento em que o Estado, as instituições privadas e demais instituições públicas reconhecem a homossexualidade como "doença" ou "conduta criminosa" fíca explícito o discurso homofóbico institucionalizado. Esse tipo de discurso nega aos gays a condição de homem igual, quanto ao uso e gozo de direitos, em razão de sua orientação sexual, colocandoos em posição de absoluta indignidade humana, reflexo da naturalização do preconceito e da discriminação. É relevante esclarecer que esse discurso homofóbico somente existe porque há pessoas que com ele se identificam, fortalecendo ainda mais a segregação sexual.

"A noção de uma homossexualidade inata nasceu na Alemanha 150 anos atrás com o advogado homossexual Karl Heinrich Ulrichs que lutou pela revogação das leis penais relativas à sodomia, evocando a existência de uma posição sexual intermediária" (VERO, 2016, p. 43). A criminalização e a patologização da homossexualidade evidencia com clareza e objetividade como as vozes do discurso homofóbico reverbera de forma natural ao longo da história da humanidade. No momento em que a modernidade pasteuriza e padroniza a sexualidade dentro de um conceito uniforme de "normalidade", exclui todos aqueles sujeitos que não se encaixaram nesse modelo imposto, além de estimular a segregação e a marginalidade.

Nesse contexto propositivo, "a homofobia se singulariza entre outras formas de discriminação, visto que enquanto já se tomaram medidas legislativas contra a discriminação 
racial, a violência contra as mulheres, os idosos e as pessoas com deficiência entre outras" (REIS, 2015, p. 58), ressalta-se que "dizer publicamente não se simpatizar ou mesmo odiar pessoas homossexuais ainda é algo não só tolerado, como constitui também em uma forma bastante comum da constituição da heterossexualidade masculina" (REIS, 2015, p. 58).

As vozes que ecoam a naturalização do discurso homofóbico são responsáveis pela exclusão, marginalidade e segregação de homens e mulheres homossexuais. "O discurso de ódio tem suas raízes na terminologia americana hate speech, podendo ser caracterizado como um instrumento que se utiliza da linguagem verbal ou extraverbal, como a fala, os gestos, a música, o cinema [...] e até o silêncio, para transmitir as manifestações de desprezo, de intolerância e de violência" (CAZELATTO; CARDIN, 2018, p. 93).

Os crimes de ódio decorrentes das mais diversas formas de se praticar a homofobia "não se resumem ao homicídio e o preconceito se manifesta muitas vezes de forma mais sutil do que a violência física, tiranizando o individuo moral e psicologicamente na sua comunidade, no seu trabalho e até mesmo no seio de sua família" (FREIRE; CARDINALI, 2012, p. 53).

A homofobia se materializa por meio de práticas e condutas veladas, expressas, violentas, obscuras, subliminares, explícitas, disfarçadas. Nem sempre as pessoas percebem claramente que praticam condutas homofóbicas, mas as vítimas sempre vivenciam essas condutas e os efeitos delas decorrentes. O discurso homofóbico é naturalizado por meio de brincadeiras, piadas e exposição de homens gays em razão de sua sexualidade. É comum gays terem que suportar esse tipo de violência reproduzido por pessoas de sua família e círculo de amigos. Todo esse círculo de violência que se retroalimenta por meio das condutas e posturas das pessoas é reflexo da cultura que dogmatiza a heterossexualidade compulsória, colocando historicamente homens e mulheres gays em posição de desigualdade e exclusão em comparação com àqueles sujeitos que aderem às proposições heterossexualizantes de uma ditadura de corpos que padroniza e pasteuriza a sexualidade humana.

“A homofobia significa a intolerância em relação à diversidade sexual, refletindo na restrição dos direitos de cidadania, de livre expressão afetivo-sexual e de identidade de gênero" (CARDIN; SEGATTO; CAZELATTO, 2017, p. 105). "A homofobia pode ser compreendida como um ódio explícito, persistente e generalizado, que se expressa por práticas sociais violentas" (NASCIMENTO, 2010, p. 229). A homofobia coisifica pessoas e 
as impedem de exercerem direitos civis básicos para o reconhecimento igual, livre e digno de sua condição humana.

\section{Portaria 158, de 4 de fevereiro de 2016 - Ministério da Saúde e a Resolução RDC} n.34, de 11 de junho de 2014 - ANVISA.

O estudo crítico da Portaria 158 do Ministério da Saúde e da Resolução 34 da ANVISA - Agência Nacional de Vigilância Sanitária constitui um meio de demonstrar no contexto da pesquisa desenvolvida que a legislação brasileira vigente é responsável por reproduzir o discurso de ódio, segregação e tratamento desigual conferido aos homossexuais, naturalizando o preconceito mediante a estigmatização de pessoas em razão de sua orientação sexual.

O artigo 64, inciso IV da Portaria 158, de 04 de fevereiro de 2016, do Ministério da Saúde, estabelece: "considerar-se-á inapto temporário por 12 (doze) meses o candidato que tenha sido exposto a qualquer uma das situações abaixo: [...] IV- homens que tiveram relações sexuais com outros homens e/ou as parceiras sexuais destes" (BRASIL, Portaria 158). A respectiva proposição legislativa evidencia a institucionalização da homofobia no momento em que considera o homem gay como integrante do grupo de risco para fins de doação de sangue. A mesma portaria estabelece em seu artigo 129 que "o serviço de hemoterapia realizará testes para infecções transmissíveis pelo sangue, a fim de reduzir riscos de transmissão de doenças e em prol da qualidade do sangue doado" (BRASIL, Portaria 158).

Se a finalidade dos bancos de doação de sangue é auferir previamente a qualidade do sangue doado, mediante exames específicos, por que ainda há a estigmatização do homem gay doador? Certamente pelo fato de o próprio Estado reconhecer expressamente que o grupo de homens gays se encontra categorizado como grupo de risco, algo que simbolicamente se relaciona com a premissa de que tais sujeitos seriam promíscuos e mais aptos às doenças sexualmente transmissíveis, simplesmente pela própria condição e orientação sexual.

Importante ainda destacar o conteúdo do artigo 2, parágrafo terceiro da Portaria 158, que é clara ao estabelecer que o objetivo dos serviços de hemoterapia é promover a melhoria da atenção e acolhimento dos candidatos à doação de sangue, mediante a realização de triagem clinica com vistas à segurança do receptor, "porém com isenção de manifestações de juízo de valor, preconceito e discriminação por orientação sexual, identidade de gênero, 
hábitos de vida, atividade profissional, condição socioeconômica, cor ou etnia, dentre outras, sem prejuízo à segurança do receptor" (BRASIL, Portaria 158).

A incongruência da portaria revela a institucionalização legal de práticas homofóbicas ao colocar o homem gay no grupo de risco dos sujeitos doadores de sangue, pois, "se por um lado a portaria garante um acolhimento isento de discriminação em razão da orientação sexual dos doadores, por outro exclui deliberadamente homens gays que tenham uma vida minimamente ativa, mesmo que em relações estáveis e com uso de preservativos" (CARDINALI, 2016, p. 116).

Uma constatação importante para evidenciar a naturalização da homofobia velada é que a referida portaria não menciona expressamente que os homens gays integram grupo de risco, mas deixa claro que se trata de sujeitos mais propensos a contrair vírus HIV e outras doenças sexualmente transmissíveis em razão da sua orientação sexual. Trata-se de proposição legislativa que expressa que esse grupo de pessoas possui condutas sexuais historicamente desviante, retroalimentando o preconceito, a estigmatização, marginalidade e exclusão dessas pessoas, justamente por não aderirem ao modelo imposto pela heteronormatividade compulsória decorrente de padrões binários preestabelecidos.

A proibição expressa de doação de sangue por homens que tenham feito sexo com outros homens, considerando-os inaptos à doação pelo prazo de 12 (doze) meses, constitui evidente afronta ao direito fundamental à igualdade e ao princípio constitucional da não discriminação. O artigo 3, inciso IV da constituição brasileira de 1988 prevê expressamente que um dos objetivos fundamentais da República Federativa do Brasil é promover o bem de todos, sem preconceito de origem, raça, sexo, cor, idade e quaisquer outras formas de discriminação. É nesse dispositivo constitucional específico que se encontra a previsão expressa do princípio da não discriminação. No momento em que o conteúdo da portaria categoriza homens gays como inaptos a doar sangue pelo prazo de 12 (doze) meses presume aprioristicamente que esses sujeitos integram grupo de risco com vulnerabilidade para a transmissão e contágio de doenças venéreas, institucionalizando a discriminação e o preconceito em razão da orientação sexual, atentando de forma direta contra disposições constitucionais. O que o Estado fez no caso em debate é institucionalizar "um grave regime de discriminação em relação a um grupo de indivíduos que estão dentro de uma categoria suspeita" (CARPINELLI, 2016, p. 46). 
Nesse sentido, verifica-se que "o princípio da igualdadeveda a discriminação para possíveis doadores com base no critério de se são ou não homens que fazem sexo com outros homens" (CARPINELLI, 2016, p. 50). "O ato regulamentar da doação de sangue reafirma a aversão homofóbica quando os impede de doar sangue sem se considerar o comportamento individual de cada homossexual, generalizando os sexualmente ativos como imprudentes" (SANTOS; BARTELLI, 2018, p. 31), além de contrariar "as conquistas obtidas para o tratamento igualitário, digno e justo perante a sociedade e a lei, ferindo a honra e instigando a continuidade do preconceito e da discriminação" (SANTOS; BARTELLI, 2018, p. 31).

O discurso homofóbico é algo que ecoa em todas as instituições, leis, provimentos, em espaços públicos e privados. Encontra-se naturalizado na sociedade civil, em razão do processo histórico regido pela heteronormatividade compulsória, que classifica pessoas, direciona escolhas individuais e padroniza condutas. " $O$ discurso homofóbico pode ser definido como um esforço permanente do sistema em excluir da categoria humano qualquer prática que fuja dos imperativos da heterossexualidade (BENTO, 2017, p. 226). "Não existe um lócus único, mapeável, em que os discursos e as práticas homofóbicas se efetivam: elas se espalham de forma descontrolada pela sociedade" (BENTO, 2017, p. 226). Na análise da respectiva portaria ora apresentada fica evidente o discurso homofóbico, que segrega, exclui e marginaliza homens gays em razão de juízos apriorísticos que os categorizam como integrantes do grupo de risco de disseminação de doenças venéreas. As proposições legislativas levantadas para o debate evidenciam mais um tipo de violência praticada contra gays, tendo em vista que "certos tipos de violências estão associados a ideais e estereótipos de gênero, ou melhor, a características e comportamentos que esperamos de homens e mulheres das relações que eles estabelecem entre si”" (LINS; MACHADO; ESCOURA, 2016, p. 55).

No mesmo sentido, o artigo 25 da Resolução RDC, número 34, de 11 de junho de 2014, da ANVISA - Agência Nacional de Vigilância Sanitária, prevê expressamente os parâmetros a serem observados na seleção de doadores de sangue, visando assegurar tanto a proteção do doador quanto a do receptor, bem como a qualidade dos produtos e a segurança em todo o processo. No inciso XXX, alínea “d”, do referido dispositivo, há a previsão expressa de que "devem ser considerados inaptos temporariamente pelo período de 12 (doze) meses após a prática sexual de risco os indivíduos do sexo masculino que tiveram relações sexuais com outros indivíduos do mesmo sexo e/ou as parceiras sexuais destes" (BRASIL, ANVISA, 2014). 
Importante ressaltar que a respectiva proposição normativa se encontra em vigor no Brasil e expressa com clareza e objetividade a institucionalização estatal do discurso de ódio contra os homossexuais do sexo masculino, ainda considerados um grupo de risco em razão da sua orientação sexual. Evidencia-se que o próprio Estado fomenta e reproduz o discurso da naturalização do preconceito, discriminação e exclusão de homens gays, categorizando-os como sujeitos com maior possibilidade de transmissão de doenças sexualmente transmissíveis, pelo simples fato de se relacionarem sexualmente com pessoas do mesmo sexo.

Simbolicamente o que se verifica a partir das proposições apresentadas é um discurso que torna natural a desigual condição suportada por homens gays em razão de sua orientação sexual. Ou seja, "a discriminação, portanto, origina-se do tratamento desigual que é formado por uma diferenciação preconceituosa que não se baseia nos indivíduos reais, mas sim uma falsa percepção produzida socialmente que desfigura a noção sobre o objeto" (LEMES, 2016, p. 195). No momento em que o próprio Estado cria dispositivo legal legitimando a desigualdade de homens gays reforça o discurso social que naturaliza tal condição vivenciada por esses sujeitos. Dessa forma, sistematiza uma premissa fundada na estigmatização da condição de ser gay como pressuposto para a proibição de ser doador de sangue. Assim, "a homofobia constrói-se a partir da atribuição de uma identidade consistente ao grupo estigmatizado, de uma capacidade para mobilizar recursos cada vez mais ocultos e de uma aptidão para apoiar-se em redes mais ou menos secretas" (BORRILLO, 2010, p. 35).

Utilizar-se da orientação sexual como critério de segregação e marginalidade do homem que se autodeclara gay, proibindo-o de exercer direitos previstos expressamente no plano legislativo, constitui um meio de institucionalizar o preconceito. Tal afirmação se justifica porque "a orientação sexual, por quem o indivíduo se sente atraído, não é algo que se escolhe ou opte" (TAQUETTE, 2015, p. 73), pois “é algo que se sente e é impossível de negar a si mesmo" (TAQUETTE, 2015, p. 73), haja vista que "parece pouco provável que, se as pessoas pudessem optar pela orientação sexual, escolheriam a homossexualidade, pois é algo socialmente discriminado, dificultado e considerado anormal, amoral e não aceito por grande parte das religiões cristãs” (TAQUETTE, 2015, p. 73).

A lei, quando utilizada para classificar corpos e pessoas a partir de critérios como a sexualidade, é vista como instrumento de reprodução da violência, fundada na institucionalização do preconceito e verdadeira afronta ao direito que cada sujeito tem de 
construir sua própria identidade. "A sexualidade humana é uma dimensão da experiência social permeada por inúmeras questões” (SEVERO, 2013, p. 69), considerando-se que “através dela, todo um universo de desejos, crenças e valores são articulados, definindo um amplo espectro de que entendemos como sendo a nossa identidade" (SEVERO, 2013, p. 69). Nesse sentido, pode-se afirmar que "por preconceito, designam-se as percepções mentais negativas em face de indivíduos e de grupos socialmente inferiorizados, bem como as representações sociais conectadas a tais percepções” (RIOS, 2007, p. 113).

O fenômeno social da homofobia constitui-se em condutas explícitas, veladas, diretas e indiretas de negativa de direitos a pessoas em razão de sua orientação sexual. O ódio aos gays é reproduzido das mais diversas formas na sociedade brasileira, por meio de atos de violência física, como mortes e agressões, como negativa de simples direitos, como o direito de liberdade de expressão no âmbito escolar ou o direito de promoção de cargo no ambiente de trabalho, tudo em razão da sua orientação sexual que contraria a doutrina da heteronormatividade compulsória. A partir desse contexto propositivo afirma-se que "a homofobia é um conjunto de crenças individuais fundadas as representações de homens e mulheres homossexuais como seres que merecem ser desprezados por não serem capazes de controlar seus desejos" (MOREIRA, 2017, p. 221).

Pelo que fora exposto até o momento resta demonstrado o interesse do Estado em assegurar a manutenção de um sistema perverso que dissemina o preconceito sexual. Em razão disso, tais diplomas legais reforçam o discurso de ódio que estimula a violência e a segregação de homens gays, proibindo-os de doarem sangue em razão da presunção generalista de que integram um grupo de sujeitos mais aptos a transmissão de doenças venéreas. Na verdade, o que o Estado faz é enaltecer e naturalizar o discurso historicamente sedimentado e fundado na premissa da desigualdade estrutural vivenciada pelos homossexuais no Brasil, reflexo da heteronormatividade compulsória construída em bases decorrentes do binarismo.

\section{Ação Direta de Inconstitucionalidade 5443 - a problemática da inconstitucionalidade} da determinação proibitiva de doação de sangue por homossexuais.

“A Ação Direta de Inconstitucionalidade n. 5443, oriunda do Distrito Federal e proposta pelo Partido Socialista Brasileiro - PSB, tem a finalidade de declarar 
inconstitucionais os dispositivos constantes na Portaria n. 158/2016, do Ministério da Saúde e RDC n. 34/2014 da ANVISA” (CRUZ, 2018).

Tanto o artigo 64, inciso IV da Portaria 158/2016 do Ministério da Saúde, assim como o artigo 25, inciso XXX, alínea "d" do RDC no 34/2014 são categóricos aos estabelecerem a proibição temporária, pelo prazo de 12 meses, de homens declaradamente gays doarem sangue. A ditadura da heteronormatividade compulsória, responsável pela sedimentação do discurso de segregação de homens gays, colocando-os no grupo de risco (pessoas com mais aptidão à transmissão de doenças venéreas), é o que explica a proibição desses sujeitos exercerem um dos direitos mais básicos da ordem normativa, qual seja, ser doador de sangue.

As respectivas normas não excepcionam a regra adotada, visto que a simples auto declaração da condição de homem gay já é suficiente para a exclusão desse sujeito em relação àqueles considerados aptos à doação de sangue, mesmo que se trate de homem gay, casado e com relacionamento monogâmico. Para que o homem gay seja reconhecido como doador de sangue deverá demonstrar que não tem atividade sexual há pelo menos 12 (doze) meses, regra essa não exigida dos demais sujeitos que integram a sociedade civil.

O objetivo do debate proposto nesse item da pesquisa é demonstrar os argumentos que evidenciam a inconstitucionalidade das respectivas proposições legislativas. Inicialmente é relevante esclarecer que a vedação imposta pelo Ministério da Saúde e ANVISA é ratificar o posicionamento estatal de considerar homens gays como sujeitos que integram grupo de risco de transmissão de doenças venéreas. Dessa forma, o Estado institucionaliza a discriminação e o tratamento desigual conferido a homem homossexual, enaltecendo-se sua marginalidade e exclusão.

“O STF iniciou o julgamento da ADI n. 5443 no dia 19/10/2017, com voto do Relator Ministro Edson Fachin pela procedência da ação e consequente declaração da inconstitucionalidade dos dispositivos impugnados" (CRUZ, 2018). No mesmo sentido, "acompanharam o voto do relator os Ministros Roberto Barroso, Rosa Weber e Luiz Fux", ressaltando-se que "o Ministro Gilmar Mendes pediu vista dos autos e o julgamento foi suspenso" (CRUZ, 2018).

Deixar de reconhecer a inconstitucionalidade da Portaria 158/2016 e do RDC n ${ }^{\circ}$ 34/2014 é o mesmo que legitimar a institucionalização do tratamento desigual e discriminatório de pessoas em razão de sua orientação sexual. Nessa perspectiva, o relator da 
ADI 5443, ministro Luiz Edson Fachin afirma que "os dispositivos em questão instituem um tratamento desigual e desrespeitoso com relação aos homossexuais [...]; a conduta é que deve definir a inaptidão para a doação de sangue, e não a orientação sexual ou o gênero da pessoa com a qual se pratica tal conduta"(CRUZ, 2018).

As proposições jurídicas trazidas pelo texto da constituição brasileira de 1988, ao instituir o Estado Democrático de Direito, instituem como fundamentos da República Federativa do Brasil a proteção da dignidade humana e o exercício da cidadania. No mesmo contexto, o artigo 3, inciso IV do texto constitucional prevê que um dos objetivos fundamentais da República Federativa do Brasil é promover o bem de todos, sem preconceito de origem raça, sexo, cor, idade e quaisquer outras formas de discriminação. A partir dessa última premissa constitucional verifica-se a sistematização teórica do princípio da nãodiscriminação, corolário da dignidade humana e dos direitos fundamentais à igualdade e liberdade, considerados pilares do Estado Democrático de Direito.

A efetivação dos direitos fundamentais, no contexto da constitucionalidade democrática, estabelece que o Estado não poderá suprimir, restringir ou obstaculizar o exercício de tais direitos em razão da orientação sexual, raça, classe social, origem, idade ou qualquer outra característica que individualiza o sujeito, porque se assim agir fomentará de maneira institucionalizada o preconceito, a segregação e a marginalidade de sujeitos em virtude das escolhas por eles realizadas no âmbito de sua subjetividade situada. Nesse sentido, os direitos fundamentais são vistos "como resultado da personificação e positivação constitucional de determinados valores básicos [...]" (SARLET, 2004, p. 70), tendo em vista que "integram, ao lado dos princípios estruturais e organizacionais [...], a substância propriamente dita, o núcleo substancial, formado pelas decisões fundamentais, da ordem normativa, revelando que mesmo num Estado constitucional democrático se tornam necessárias" (SARLET, 2004, p. 70).

O primeiro dispositivo constitucional violado expressamente pela portaria 158 , do Ministério da Saúde, e resolução RDC 34 da ANVISA, é o artigo 1., incisos II e III, que estabelece como um dos fundamentos do Estado Democrático de Direito a proteção integral da dignidade humana e o exercício da cidadania. A partir desse contexto propositivo é relevante destacar que "a dignidade humana corretamente compreendida está relacionada ao autorrespeito, como a ideia segundo a qual toda e qualquer vida é importante e tem o mesmo valor, e à autenticidade, relacionada à ideia segundo a qual cabe a cada ser humano 
desenvolver livremente seus projetos de felicidade" (OMMATI, 2018, p. 23). Assim, "não é possível pensar em igual valor da vida humana, dimensão central do autorrespeito, sem que sejam asseguradas condições mínimas de sobrevivência e subsistência, aquilo que é designado por mínimo existencial” (OMMATI, 2018, p. 23).

Negar o direito de homens gays serem doadores de sangue, em razão de sua orientação sexual, é o mesmo que colocá-los numa condição subumana, excluindo-os do exercício efetivo da cidadania, já que são impedidos de gozar do exercício de direitos civis básicos.

No momento em que as instituições estatais proíbem homens gays de doarem sangue retira-lhes a condição digna de vida, coisificando-os e conferindo-lhes tratamento jurídico desigual, contrário as proposições normativas trazidas pela constituição brasileira de 1988 . Trata-se de um exemplo clássico de utilização do texto legal como mecanismo de formalização da homofobia, visto que a orientação sexual do sujeito é utilizada como critério regente para desigualá-lo em comparação com os demais sujeitos. Ademais, verifica-se que "o impedimento que os dispositivos atacados na ADI 5543 vedam, choca-se frontalmente com os princípios constitucionais da igualdade, proporcionalidade e razoabilidade (art. $5^{\circ}$, caput e LIV, CRFB/88)" (CRUZ, 2018), bem como "da dignidade humana (art. 1º, III, CRFB/88) e com os objetivos da República de construir sociedade justa e solidária, reduzir desigualdades sociais e promover o bem de todos, sem preconceitos de sexo e outras formas de discriminação (art. 3º, I, III e IV, CRFB/88) (CRUZ, 2018).

A dignidade humana é uma premissa constitucional considerada referencial para o exercício dos direitos fundamentais, como é o caso da liberdade e igualdade. O homem será livre e igual quando for juridicamente protegido em suas escolhas individuais, não podendo ser segregado em virtude de questões atreladas a sua subjetividade, como é o caso da orientação sexual. Negar direitos a alguém em virtude de suas escolhas individuais, que em nada afetam a esfera pública, constitui um meio ilegítimo de utilização da norma jurídica como ferramenta para discriminar e fomentar o preconceito. É nesse sentido que "a dignidade da pessoa humana, consagrada como princípio fundamental da Constituição Federal de 1988, revela-se também na capacidade de autodeterminação da vontade, ou seja, componente essencial da liberdade humana" (CRUZ, 2018). Na medida em que a liberdade de escolha é protegida e priorizada mais igualdade de tratamento jurídico é conferido aos titulares dos direitos fundamentais, assegurando-lhes uma vida mais digna e menos desigual. 
O segundo dispositivo constitucional diretamente violado pela portaria 158 , do Ministério da Saúde, e resolução RDC 34 da ANVISA, é o artigo 3., inciso IV do texto constitucional, que é claro ao estabelecer que é dever do Estado promover o bem de todos, sem distinções de origem, raça, sexo, cor, idade ou quaisquer outras formas de discriminações. Sistematiza-se, nesse ínterim, o princípio da não-discriminação, cujo entendimento hermenêutico e democrático-constitucionalizado é no sentido de demonstrar que a norma jurídica não pode ser utilizada como meio para ratificar a desigualdade e discriminação socialmente existente.

Conforme anteriormente exposto, o processo histórico brasileiro foi construído a partir das premissas binário-sexistas, reflexo da doutrina da heteronormatividade compulsória, ou seja, o arcabouço normativo brasileiro foi genuinamente estruturado para proteger pessoas heterossexuais, cuja orientação sexual e identidade de gênero sejam compatíveis com as premissas trazidas e impostas pela modernidade. Em contrapartida, o texto constitucional vigente privilegia a igualdade de gênero, a vedação do preconceito sexual, a igualdade das pessoas no que atine ao exercício dos direitos fundamentais previstos no plano constituinte, além da liberdade de escolha na construção da subjetividade situada. É por isso que o Estado não pode intervir no sentido negar o exercício de direitos em razão das escolhas individuais dos sujeitos no âmbito de sua sexualidade, uma vez que "na medida em que se garanta a qualquer indivíduo que pontue suas atitudes de acordo com o próprio e livre entendimento, materializada estará a dignidade humana (CRUZ, 2018).

O artigo 5., caput, da constituição brasileira de 1988 é claro ao prever, dentre seu rol exemplificativo de direitos fundamentais, a liberdade e a igualdade. Tais direitos devem ser interpretados de forma sistemática, extensiva, de modo a assegurar a proteção integral da pessoa humana no que atine as suas escolhas individuais, integridade física, moral, psicológica. Qualquer tratamento desigual e discriminatório conferido normativamente afronta o texto constitucional e, por isso, exigir que homens gays somente poderão doar sangue após comprovarem que estão há 12 (doze) meses sem atividade sexual é o mesmo que impor que se abstenham de exercer sua liberdade sexual.

Uma das principais justificativas utilizadas para explicar a proibição de homens gays doarem sangue é que a prática de sexo anal traria maiores riscos de transmissão de doenças, em termos comparativos com o sexo vaginal, haja vista que o ânus é uma região vascularizada e com muita possibilidade de sangramentos. A respectiva justificativa, além de preconceituosa 
e de evidenciar clara institucionalização da homofobia, desconsidera o fato de que a prática do sexo anal não é uma prerrogativa exclusiva de homens gays, uma vez que os riscos decorrentes das relações sexuais desprotegidas existem independentemente da orientação sexual e do gênero dos indivíduos envolvidos. Ademais, não se pode desconsiderar que existe uma parcela de casais heterossexuais que faz sexo anal e, nem por isso, são proibidos de doarem sangue, razões essas que reforçam a tese da inconstitucionalidade de tais dispositivos legais.

Pensar e interpretar o ordenamento constitucional sob a ótica da dignidade humana, direitos fundamentais à liberdade e igualdade, bem como o princípio da não-discriminação é uma forma de reconhecer o fundamento ético da ciência do direito. A finalidade do direito democrático é assegurar a ampla e integral proteção da pessoa humana, seja no âmbito individual ou coletivo, primando pelo tratamento igual no exercício dos direitos fundamentais, além de reconhecer a liberdade de escolha no que tange à construção de sua individualidade. Assim, "a dignidade humana, como valor máximo do sistema jurídico, permite a realização plena da pessoa, nos diversos espaços existenciais (como na família, na empresa, no sindicato, na universidade ou em quaisquer microcosmos contratuais), de forma isonômica, respeitando-se a ótica da solidariedade constitucional” (CRUZ, 2018).

A liberdade de autodeterminação conferida a cada sujeito é um dos desdobramentos interpretativos da dignidade humana, compreendida como corolário da igualdade e liberdade. Nesse sentido, qualquer previsão normativa construída com o objetivo de desqualificar o exercício digno da liberdade sexual possui nítido caráter discriminatório, institucionalizando a intolerância, segregação sexual, preconceito e marginalidade de homens gays, num reflexo claro da naturalização da homofobia. Por isso, "a liberdade de orientação sexual é, portanto, aspecto essencial da autodeterminação da pessoa e impor restrições desarrazoadas a tal liberdade afasta de seu centro de identidade o próprio estado de direito" (CRUZ, 2018).

A principal finalidade da política nacional de doação de sangue é a promoção da vida, proteção da saúde dos enfermos, sendo irrelevante saber se o sangue doado vem de pessoas negras, pobres, ricas, gays, lésbicas ou gays. Constitui dever de o Estado instituir critérios para a doação, desde que tais critérios não sejam segregacionistas e privilegiem o objetivo central da política nacional de doação de sangue, que é o estimulo da iniciativa de mais pessoas terem interesse em doar. Criar requisitos legais para categorizar aqueles que podem ou não doar, em razão de suas escolhas individuais, além de constituir um meio formal 
de discriminação, evidencia a ingerência do Estado em não privilegiar políticas públicas de igualdade de gênero, visto que estigmatizam pessoas em razão de sua orientação sexual. "A esse respeito, quando se observa o princípio da igualdade percebe-se que o impedimento a doação de sangue pelo período de 12 meses para homens que tiverem relações sexuais com outros homens [...] constitui claramente como medida de discriminação, uma vez que se pauta exclusivamente na orientação sexual do indivíduo" (CRUZ, 2018).

Os requisitos adotados no processo de doação de sangue devem objetivar que o sangue doado não seja contaminado por doenças transmissíveis por transfusão sanguínea. Para isso, as centrais de doação de sangue devem dispor de uma estrutura para realização de exames para averiguação da qualidade do sangue coletado, antes que o mesmo seja disponibilizado para transfusão. Não é possível concluir preliminarmente que sangue doado por determinada categoria de pessoas é contaminado por possíveis doenças transmissíveis via transfusão, tendo em vista que a utilização de tal critério configura meio de estigmatizar determinadas categorias de pessoas como aprioristicamente inaptas à doação, por integrarem grupo de risco, tal como ocorre com a previsão legal de proibição de doação de sangue por homens declaradamente gays.

O risco de contaminação de doenças via transfusão de sangue existe independentemente da pessoa que o doou, ressaltando-se que a minimização desse risco somente ocorre mediante exames laboratoriais, obrigatório para todo sangue coletado. Se tais exames são obrigatórios para todo o sangue coletado, qual é a razão que justifica a proibição legal de homens gays serem doadores? Tal vedação legal decorre da pressuposta concepção adotada pelo Estado, de que tais homens integram grupo de risco de transmissão de doenças venéreas, em razão de sua orientação sexual que destoa da heteronormatividade compulsória imposta pela doutrina do binarismo.

Tais premissas reforçam os argumentos da inconstitucionalidade da portaria 158 , do Ministério da Saúde, e resolução RDC 34 da ANVISA, visto que afronta a dignidade humana, viola o princípio da vedação de discriminação, além de constituir evidente negativa de efetivação dos direitos fundamentais a liberdade sexual e igualdade de gênero. Mesmo diante de todo esse contexto exposto, alguns tribunais de justiça têm negado o direito de o homem gay ser indenizado por danos morais, quando proibido de doar sangue, por entenderem os respectivos tribunais que não existe ato ilícito passível de reparação, mascarando novamente a homofobia institucionalizada. O Tribunal de Justiça do Rio Grande do Sul, no julgamento da 
apelação 70079111712 posicionou-se contrário ao pleito indenizatório de homem gay proibido de doar sangue (BRASIL, Tribunal de Justiça do Rio Grande do Sul, 2018); o Tribunal de Justiça do Pará, no julgamento da apelação 200730082944, no mesmo sentido se posicionou contrariamente ao direito de indenização por danos morais, por entender inexistir ato ilícito (BRASIL, Tribunal de Justiça do Pará, 2007).

O entendimento atual adotado pela legislação e judiciário brasileiro deixa claro o fenômeno social da naturalização e institucionalização da homofobia, mantendo o estigma social de que homens gays integram grupo de risco e, por isso, são considerados, sob o ponto de vista legal e jurisdicional, inaptos a doação de sangue.

\section{Conclusão}

A homofobia é um fenômeno social que historicamente reproduz o discurso de ódio contra homens e mulheres em razão da sua orientação sexual. A doutrina binário-sexista de classificação de corpos e pessoas, a partir dos parâmetros propostos e impostos pela heteronormatividade compulsória, fomenta o preconceito, segrega pessoas, marginaliza sujeitos em razão de sua orientação sexual. Os reflexos desse contexto são a naturalização e a institucionalização de práticas homofóbicas veladas e explícitas, todas elas voltadas à estigmatização daqueles que não reproduzem o modelo heterossexualizante vigente, como é o caso dos homens gays.

A portaria 158/2016 do Ministério da Saúde e a resolução 34/2014 da Agência Nacional de Vigilância Sanitária institucionalizaram no Brasil a homofobia legal, ao proibir homens gays de doarem sangue. Os respectivos dispositivos legais exigem que o homem declaradamente gay comprove não se relacionar sexualmente com outros homens há mais de 12 (doze) meses, como condição para doar sangue. Sem pretender justificar explicitamente a medida, tais provimentos legislativos proíbem a doação de sangue de homens gays por considerá-los como integrantes do grupo de risco com maior propensão de transmissão de doenças venéreas, pelo simples fato desses sujeitos não reproduzirem a máxima imposta pela heteronormatividade compulsória.

O estudo desenvolvido a partir da análise da ação direta de inconstitucionalidade 5443, verificou-se que tais previsões legais afrontam o texto da constituição brasileira de 1988. O primeiro dispositivo constitucional violado é o artigo 1, incisos II e III, que preveem 
a dignidade humana e a cidadania como um dos fundamentos da República Federativa do Brasil. A proibição legal de homens gays doarem sangue os colocam em posição de absoluta indignidade, tornando inviável o exercício da cidadania no Estado Democrático de Direito, que exige o gozo dos direitos civis e fundamentais básicos, como é o caso do direito de doar sangue.

Outro dispositivo constitucional violado é o artigo 3, inciso IV, que estabelece como objetivo fundamental da República Federativa do Brasil promover o bem de todos, sem distinção de origem, raça, sexo, cor, idade ou quaisquer outras formas de discriminações. $\mathrm{Na}$ respectiva norma constitucional encontra-se o princípio da não-discriminação, que proíbe que provimentos estatais tornem inviável o exercício de direitos fundamentais pelos seus titulares, em razão das escolhas que cada cidadão faz no âmbito de sua sexualidade. No mesmo sentido, o artigo 5, caput, prevê dentre o rol exemplificativo de direitos fundamentais a liberdade e a igualdade. A partir da interpretação sistemático-constitucionalizada e extensiva, a liberdade se efetiva no momento em que o Estado não intervém nas escolhas pessoais de cada indivíduo e não impossibilita pessoas de gozarem dos direitos previstos no plano legislativo em virtude de sua subjetividade. A igualdade no gozo de direitos exige uma legislação que não discrimine, segregue ou marginaliza pessoas em decorrência de sua orientação sexual.

A partir das premissas expostas conclui-se que a portaria 158/2016 do Ministério da Saúde e a resolução 34/2014 da Agência Nacional de Vigilância Sanitária são inconstitucionais, haja vista a ofensa direta do princípio da dignidade humana, limitação quanto ao exercício da cidadania por homens declaradamente gays, violação do princípio da não-discriminação, além da supressão do direito de liberdade de escolha quanto à forma como viverá a sexualidade e o tratamento explicitamente desigual no que tange ao gozo efetivo dos direitos civis em razão especificamente da orientação sexual. Manter as respectivas legislações vigentes e em vigor no ordenamento jurídico brasileiro constitui um meio de utilizar a ciência do direito como instrumento de segregação, exclusão, marginalidade, discriminação e preconceito contra homens gays, reproduzindo o padrão histórico-social sistematizado pela modernidade.

\section{Referências}


BORRILLO, Daniel. HOMOFOBIA - História e crítica de um preconceito. Belo Horizonte: Autêntica, 2010.

BRASIL. ANVISA - Agência Nacional de Vigilância Sanitária. Resolução - RDC N.34, de 11 de junho de 2014. Disponível em https://saude.rs.gov.br/upload/arquivos/carga20170553/04145350-rdc-anvisa-34-2014.pdf. Acesso em 23 jun. 2019.

BRASIL. Tribunal de Justiça do Rio Grande do Sul, 2018. Disponível em https://tjrs.jusbrasil.com.br/jurisprudencia/652362344/apelacao-civel-ac-70079111712-rs/inteiro-teor652362355?ref=serp. Acesso em 23 ago. 2019.

BRASIL. Tribunal de Justiça do Pará, 2007. Disponível em https://tjpa.jusbrasil.com.br/jurisprudencia/5545424/apelacao-civel-ac-200730082944-pa-200730082944?ref=serp. Acesso em 22 ago. 2019.

BRASIL. Portaria 158, de 04 de fevereiro de 2016. Disponível em http://bvsms.saude.gov.br/bvs/saudelegis/gm/2016/prt0158_04_02_2016.html, Acesso em 30 jun. 2019.

BRASIL. Jornal Folha de São Paulo. Disponível em https://www1.folha.uol.com.br/mundo/2019/03/relacao-homossexual-e-crime-em-70-paisesmostra-relatorio-mundial.shtml. Acesso em 17 ago. 2019.

BENTO, Berenice. TRANSVIADAS - gênero, sexualidade e direitos humanos. Salvador: EDUFBA, 2017.

BUTLER, Judith. PROBLEMAS DE GÊNERO - feminismo e subversão da identidade. Rio de Janeiro: Civilização Brasileira, 2015.

CARDIN, Valéria Silva Galdino; SEGATTO, Antônio Carlos; CAZELATTO, Caio Eduardo Costa. O EXERCÍCIO ILEGÍTIMO DO DISCURSO DE ÓDIO HOMOFÓBICO SOB A ÓTICA DA SEXUALIDADE E DA DIGNIDADE HUMANA. Revista Jurídica. vol. 01, n. 46, Curitiba, 2017. pp. 90-118. Disponível em

http://revista.unicuritiba.edu.br/index.php/RevJur/article/view/2001/1282. Acesso em 20 ago. 2019.

CARDINALI, Daniel Carvalho. A proibição de doação de sangue por homens homossexuais: uma análise sob as teorias do reconhecimento de Fraser e Honneth. Revista Digital

Constituição e Garantia de Direitos, v.9, n.2, 2016. Disponível em https://periodicos.ufrn.br/constituicaoegarantiadedireitos/article/view/12256. Acesso em 30 jun. 2019.

CARPINELLI, André de Paula Turella. A doação de sangue por homens que fazem sexo com outros homens à luz do princípio da igualdade no direito brasileiro. Revista Jurídica Iuris In Mente Direitos Fundamentais e Políticas Públicas, v.1, n.1, 2016. Disponível em http://www.periodicos.ulbra.br/index.php/iuris/article/view/2245/1588. Acesso em 30 jun. 2019. 
CAZELATTO, Caio Eduardo Costa; CARDIN, Valéria Silva Galdino. DISCURSO DE ÓDIO E MINORIAS SEXUAIS. Rio de Janeiro: Lumen Juris, 2018.

CRUZ, Antônio Átila Silva da. A (in)constitucionalidade da restrição à doação de sangue por homens homossexuais: ADI 5543. Jus Brasil. Disponível em https://jus.com.br/artigos/67337/a-in-constitucionalidade-da-restricao-a-doacao-de-sanguepor-homens-homossexuais-adi-5543. Acesso em 20 jul. 2019.

FREIRE, Lucas; CARDINALI, Daniel. O ódio atrás das grades: da construção social da discriminação por orientação sexual à criminalização da homofobia. Sexualidad, Salud y Sociedad . Revista Latinoamericana, n.12 . dec. 2012 . pp.37.63. Disponível em https://www.redalyc.org/pdf/2933/293324656003.pdf. Acesso em 20 ago. 2019.

LEMES, Gustavo. O que é discurso de ódio? GÊNERO, SEXUALIDADE E DIREITO uma introdução. Organização Marcelo Maciel Ramos; Paula Rocha Gouvêa Brener; Pedro Augusto Gravatá Nicoli. Belo Horizonte: Initia Via, 2016.

LINS. Beatriz Accioly; MACHADO, Bernardo Fonseca; ESCOURA, Michele. DIFERENTES, NÃO DESIGUAIS - A questão de gênero na escola. São Paulo: Editora Reviravolta, 2016.

MELO, Ferdinando Santos de. Gênero, Orientação Sexual e Educação: reflexões conceituais e interfaces com o serviço social e a diversidade na escola. EDUCAÇÃO E IGUALDADE DE GÊNERO. Organização: Alfrâncio Ferreira Dias; Maria Helena Santana Cruz. Jundiaí: Paco Editorial, 2015.

MOREIRA, Adilson José. CIDADANIA SEXUAL - Estratégia para Ações Inclusivas. Belo Horizonte: Arraes, 2017.

NASCIMENTO, Márcio Alessandro Neman do. Homofobia e homofobia interiorizada: produções subjetivas de controle heteronormativo? Athenea Digital - núm. 17: 227-239 (marzo 2010). Disponível em https://atheneadigital.net/article/view/n17-nascimento/652-pdfpt. Acesso em 20 ago. 2019.

OMMATI, José Emílio Medauar. Uma teoria dos direitos fundamentais. 5.ed. Rio de Janeiro: Lumen Juris, 2018.

RIOS, Roger Raupp. O conceito de homofobia na perspectiva dos direitos humanos e no contexto dos estudos sobre preconceito e discriminação. EM DEFESA DOS DIREITOS SEXUAIS. Organizador Roger Raupp Rios. Porto Alegre: Livraria do Advogado, 2007.

SARLET, Ingo Wolfgang. A eficácia dos direitos fundamentais. 4.ed. Porto Alegre: Livraria do Advogado, 2004.

SANTOS, Júlia Caroline Xavier dos; BARTELLI, Danielle Regina. A inconstitucionalidade e homofobia na portaria que regulamenta a doação de sangue no Brasil. Responsabilidade do

Revista de Gênero, Sexualidade e Direito | e-ISSN: 2525-9849 | Belém | v. 5 | n. 2 | p. 33 - 54 | Jul/Dez. 2019. 
Estado. Organização Jaime Domingues Brito; Tiago CappiJanini; Moacyr Miguel de Oliveira. Anais do VIII Simpósio de Análise Crítica do Direito. 1.ed. Jacarezinho: UENP, 2018. Disponível em http://siacrid.com.br/repositorio/2018/responsabilidade-doestado.pdf\#page=20. Acesso em 30 jun. 2019.

SANTOS, Fábio. Homossexualidade não é doença segundo a OMS. Disponível em https://www.terra.com.br/vida-e-estilo/saude/ha-21-anos-homossexualismo-deixou-de-serconsiderado-doenca-pela-oms,0bb88c3d10f27310VgnCLD100000bbcceb0aRCRD.html. Acesso em 17 ago. 2019.

SEVERO, Rafael Adriano de Oliveira. GÊNERO \& SEXUALIDADE - Grupos de Discussão como Possibilidade Formativa. Jundiaí: Paco Editorial, 2013.

TAQUETTE, Stella R. HOMOSSEXUALIDADE E ADOLESCÊNCIA sob a ótica da saúde. Rio de Janeiro: EdUERJ, 2015.

VERO, Justino. Por falar em preconceito e gênero... Rio de Janeiro: GZ Editora, 2016. 